\title{
PRECIPITATION CHEMISTRY TRENDS IN THE NORTHEASTERN UNITED STATES
}

\section{by}

Gary J. Stensland

Illinois State Water Survey Urbana, IL 61801

For presentation at the Twelfth Annual Rochester International Conference on Environmental Toxicity, 21-23. May 1979 and subsequent publication by Plenum Press. The conference is held at the University of Rochester Medical Center, Rochester, New York, and is entitled "Polluted Rain."
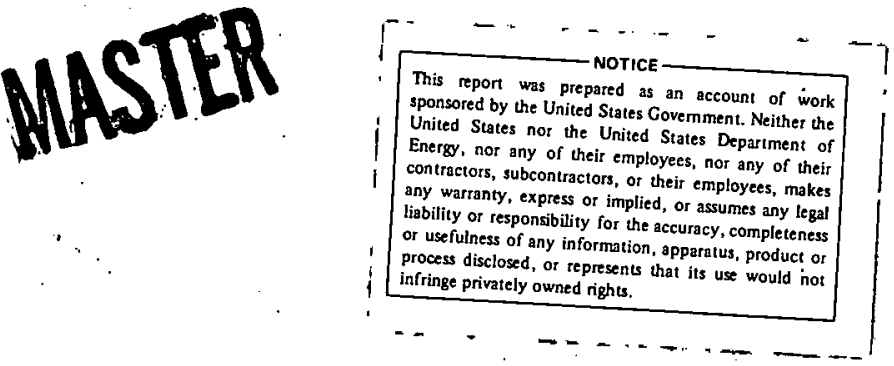


\section{DISCLAIMER}

This report was prepared as an account of work sponsored by an agency of the United States Government. Neither the United States Government nor any agency Thereof, nor any of their employees, makes any warranty, express or implied, or assumes any legal liability or responsibility for the accuracy, completeness, or usefulness of any information, apparatus, product, or process disclosed, or represents that its use would not infringe privately owned rights. Reference herein to any specific commercial product, process, or service by trade name, trademark, manufacturer, or otherwise does not necessarily constitute or imply its endorsement, recommendation, or favoring by the United States Government or any agency thereof. The views and opinions of authors expressed herein do not necessarily state or reflect those of the United States Government or any agency thereof. 


\section{DISCLAIMER}

Portions of this document may be illegible in electronic image products. Images are produced from the best available original document. 
Gary J. Stensland

I1linois State Water Survey

P. 0. Box 232

Urbana, IL 61801

\section{INTRODUCTION}

Gases and particles injected into the atmosphere by natural. or anthropogenic sources are returned to the earth's surface through wet and dry removal processes. Therefore historical trends of the concentrations of the various trace substances in precipitation can serve as an indication of the changes in the levels of these substances in the air.

This paper will examine three topies related to the precipitation chemistry data base for the United States. First, since the $\mathrm{pH}$ of precipitation is of major interest, techniques to calculate this quantity will be considered. This calculation is necessary when the $\mathrm{pH}$ was not reported, as is frequently the case for the older data sets. Next, the changes in the precipitation chemistry for a central Illinois site will be discussed. This site is at the western edge of present high atmospheric sulfate levels, and thus it is interesting to examine changes in the precipitation $\mathrm{pH}$ at this site and the reasons for them. The third and final topic will be to consider changes in the sulfate and nitrate at this central Illinois site and other sites further East, and to compare these changes to the time trends in the anthropogenic source emissions.

\section{METHODS TO CALCULATE PRECIPITATION $\mathrm{pH}$}

The 1954 data set to be discussed in the next section of this paper did not include $\mathrm{pH}$ measurements so the following procedure has been used to calculate the pH. ${ }^{1,2}$ In a rain or melted snow 


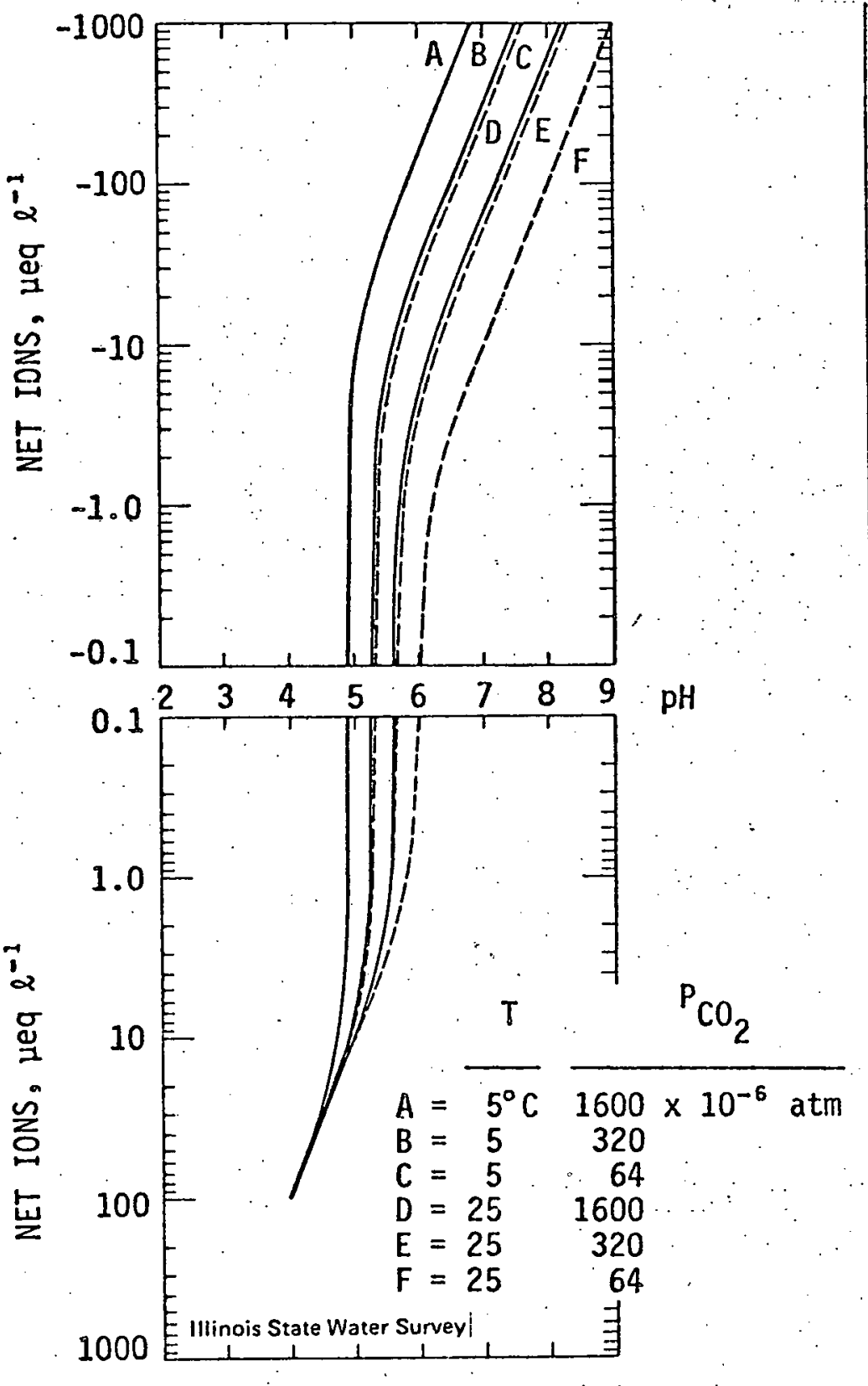

Figure 1. The concentration of Net Ions versus $\mathrm{pH}$ for precipitation samples with different values of $T$ (temperature) and $\mathrm{P}_{\mathrm{CO}_{2}}$ (from ref. 2).

limited data base. The ratio was $\gg 1$ except along the sea coasts. The results of these calculations are shown in Figure 2, where the median of the calculated $\mathrm{pH}$ values for each measured $\mathrm{pH}$ class $(0.1$ unit in width) are plotted. The line segments which have been fitted to the data points can be used to correct the calculated $\mathrm{pH}$ 
solution, a charge balance is maintained. If a term called Net Ions is defined as

$$
\begin{aligned}
(\text { Net Ions }) & =\left(\mathrm{SO}_{4}^{=}\right)+\left(\mathrm{NO}_{3}^{-}\right)+\left(\mathrm{Cl}^{-}\right)-\left(\mathrm{Ca}^{++}\right)-\left(\mathrm{Mg}^{++}\right)-\left(\mathrm{NH}_{4}^{+}\right) \\
& -\left(\mathrm{Na}^{+}\right)-\left(\mathrm{K}^{+}\right),
\end{aligned}
$$

then the charge balance equation, consisting of the major ions, is

$$
\left(\mathrm{H}^{+}\right)-\left(\mathrm{HCO}_{3}^{-}\right)=(\text {Net Ions }) \text {. }
$$

with each concentration in units of microequivalents per liter $(\mu \mathrm{eq} / \mathrm{l})$.. Although Eq. 2 is not exactly correct, since some ions have not been included, the relation has been found to work reasonably well for rain and snow samples. With the appropriate chemical equilibrium constants, it can be shown that $\left(\mathrm{HCO}_{3}^{-}\right) \simeq 490\left(\mathrm{OH}^{-}\right)$and for samples with $\mathrm{pH}<8,\left(\mathrm{CO}_{3}\right)<<\left(\mathrm{HCO}_{3}^{-}\right)$. Thus, the two ions $\mathrm{OH}^{-}$and $\mathrm{CO}_{3}$, need not be considered in the charge balance equation. Assuming that falling raindrops are in equilibrium with atmospheric carbon dioxide $\left(\mathrm{P}_{\mathrm{CO}_{2}}=320 \times 10^{-6} \mathrm{~atm}\right)$, then the chemical equilibria relationships can be used to give

$$
\left(\mathrm{HCO}_{3}^{-}\right)=\mathrm{K}_{\mathrm{H}} \mathrm{K}_{1} \mathrm{P}_{\mathrm{CO}_{2}} /\left(\mathrm{H}^{+}\right)
$$

where $K_{H}$ is the constant in Henry's Law and $K_{1}$ is the first disassociation constant of $\mathrm{CO}_{2}$ in water (for $25^{\circ} \mathrm{C}, \mathrm{K}_{\mathrm{H}}=0.034 \times 10^{+6}$ $\mu \mathrm{eq} / \mathrm{l} / \mathrm{atm}$ and $\mathrm{K}_{1}=4.5 \times 10^{-1} \mu \mathrm{eq} / \mathrm{l}$ ). Substituting Eq. 3 into Eq. 2 and solving the quadratic equation for $\left(\mathrm{H}^{+}\right)$gives

$$
\left(\mathrm{H}^{+}\right)=\left\{(\text {Net Ions }) \pm\left[(\text { Net Ions })^{2}+\left(4 \mathrm{~K}_{\mathrm{H}} \mathrm{K}_{1} \mathrm{P}_{\mathrm{Co}_{2}}\right)\right]^{0.5}\right\} / 2 \text {. }
$$

In Eq. 4, only the plus sign in front of the bracketed term gives positive and therefore physically realistic solutions. Eq. 4 is rewritten in terms of $\mathrm{pH}$ as

$$
\mathrm{pH}=+6-\log _{10}\left\{\left\{(\text { Net Ions })+\left[(\text { Net Ions })^{2}+\left(4 \mathrm{~K}_{\mathrm{H}} \mathrm{K}_{1} \mathrm{P}_{\mathrm{CO}_{2}}\right)\right]^{0.5}\right\} / 2\right\}
$$

where the +6 factor results from the fact that the $\mu$ eq/ $l$ concentration unit is required for the terms in Eq. 5. Figure 1 illustrates Eq. 5 for a variety of temperature $T$ and $P_{\mathrm{CO} 2}$ values. Curve $E$ was used to calculate the $\mathrm{pH}$ for the 1954 data.

From 1959 to 1964 the U. S. Public Health Service collected monthly precipitation samples at 39 locations throughout the continental United States. Equation 5 was used to calculate the pH values for this data set of 1295 samples. $\mathrm{Mg}^{++}$was not reported so it was estimated by assuming it to be related to $\mathrm{Ca}^{+H}$, with the $\left(\mathrm{Ca}^{+}\right) /\left(\mathrm{Mg}^{++}\right)$ratio being assigned regional values based on a very 


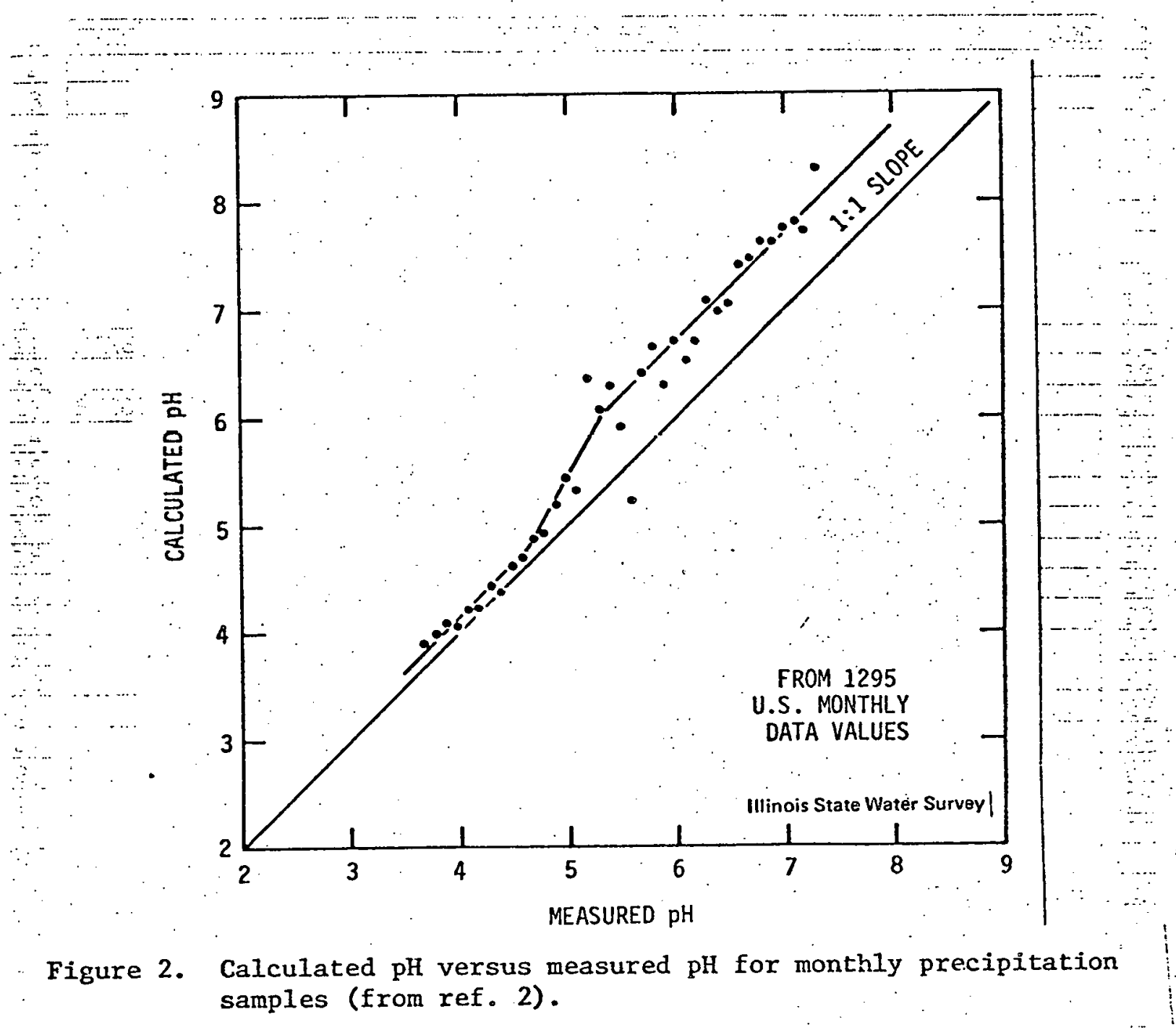

values such that they will agree with the measured $\mathrm{pH}$ values. The equations for the three line segments are

$$
\mathrm{pH}(\text { corrected })=\mathrm{pH}(\text { calculated })-\mathrm{C} \text {, }
$$

where $\mathrm{C}=0.70$ for $\mathrm{pH}$ (calculated) $\geq 6.0$ and $\mathrm{C}=0.15$ for $\mathrm{pH}$ (calculated) $\leq 4.8$, and

$$
\mathrm{pH}(\text { corrected })=0.54 \mathrm{pH} \text { (calculated })+2.06 \text {, }
$$

for $4.8<\mathrm{pH}$ (calculated) < 6.0. The data reported by Granat, ${ }^{3}$ for about 1500 monthly samples from the European chemistry network, were also used to prepare a graph like Figure 2. Equations 6 and 7 also fit the Granat data very well. A firm explanation as to why Eqs. 6 and 7 are needed for the precipitation data is not yet available.

Finally, with respect to calculating $\mathrm{pH}$, Eq. I can be conpared with two other somewhat different approaches in the literature. 
Granat ${ }^{3}$ assumed that all the $\mathrm{Na}^{+}$and $\mathrm{Cl}^{-}$were due to sea salt and thus neither ion was included in his equations. Also the other ions were corrected for sea salt. Granat's final equation, expressed in the form of Eq. 1, was

$$
\begin{aligned}
(\mathrm{Net} \text { Ions })_{\mathrm{GRAN}} & =\left(\mathrm{SO}_{4}^{=}-\mathrm{SSSO}_{4}^{=}\right)+\left(\mathrm{NO}_{3}^{-}\right)-\left(\mathrm{Ca}^{++}-\mathrm{SSCa}^{++}\right)-\left(\mathrm{Mg}^{++}\right. \\
& \left.-\mathrm{SSMg}^{++}\right)-\left(\mathrm{NH}_{4}^{+}\right)-\left(\mathrm{K}^{+}-\mathrm{SSK}^{+}\right)
\end{aligned}
$$

The SS prefix for an ion indicates that the quantity is the amount due to sea salt, $\mathrm{Na}^{+}$being used by Granat as the reference sea salt ion.

Cogbili and Likens ${ }^{4}$ also corrected each ion for sea salt but included $\mathrm{Na}^{+}$or $\mathrm{Cl}^{-}$in the final equation. For example, if $\left(\mathrm{Na}^{+}\right) /$ (C1-) was greater than the ratio for sea water, then the excess $\mathrm{Na}^{+}$. was included in the equation and the base ion for making the sea salt correction was $\mathrm{Cl}^{-}$. In this case the final equation, expressed in the form of $E q .1$, was

$$
\begin{aligned}
\text { (Net Ions) } \mathrm{COG}=\left(\mathrm{SO}_{4}^{=}-\mathrm{SSSO}_{4}^{-}\right)+\left(\mathrm{NO}_{3}^{-}\right)-\left(\mathrm{Ca}^{++}-\mathrm{SSCa}^{++}\right)-\left(\mathrm{Mg}^{-+}\right. \\
\left.-\mathrm{SSMg}^{++}\right)-\left(\mathrm{NH}_{4}^{+}\right)-\left(\mathrm{Na}^{+}-\mathrm{SSNa}^{+}\right)-\left(\mathrm{K}^{+}-\mathrm{SSK}^{+}\right) .
\end{aligned}
$$

Equations 8 and 9 were used in place of Eq. 1 to produce equations analogous to Eq. 5. The three $\mathrm{pH}$ equations were then applied to the same data set, namely Junge's 1955-1956 data for 63 sites in the United States. ${ }^{5} \mathrm{Mg}^{++}$was not reported by Junge so regional ratios of $\mathrm{Ca}^{++}$to $\mathrm{Mg}^{++}$were used to estimate $\mathrm{Mg}^{++}$, as was previously discussed. Also, Junge reported only quarterly values for $\mathrm{NH}_{4}$ and $\mathrm{NO}_{3}^{-}$. Thus, these values were weighted with the quarterly precipitation at the sites to produce annual averages for $\mathrm{NO}_{3}^{-}$and $\mathrm{NH}_{4}^{+}$.

The $\mathrm{pH}$ results are shown in Figures 3 and 4. In Figure 3 the pH values from Eq. 5 are plotted on the abscissa and the values with the assumptions of Cogbill and Likens are plotted on the ordinate. The agreement is very good, with the linear correlation coefficient $r=0.99$. In Figure 4, the results from Eq. 5 are compared with the $\mathrm{pH}$ values using Granat's assumptions. The agreement is not as good, with $r=0.90$ and the line of best fit being $\mathrm{y}=0.96 \mathrm{x}$. The $\mathrm{pH}$ values calculated with Granat's sea salt assumptions are generally lower than those calculated by Stensland with Eq. 5, a change which is in the same direction as that resulting from the empirical correction in Figure 2. Therefore, if the empirical corrections in Eq. 6 and 7 are not used, then the pH calculated with Granat's assumptions would probably agree better with measured $\mathrm{pH}$ values than if the assumptions of Cogbill and Likens or Stensland were used. 


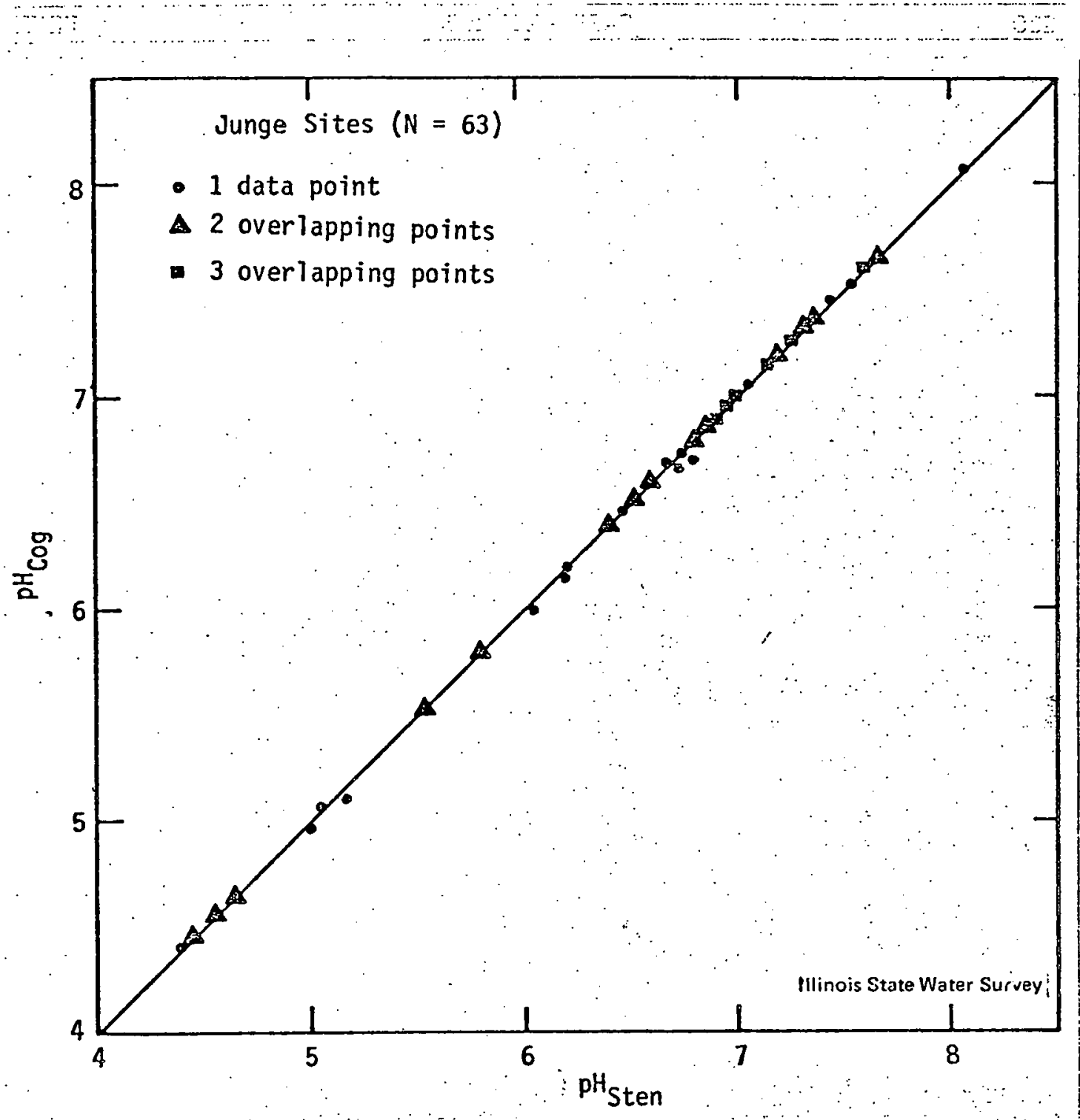

Figure 3. The pH calculated with the assumptions made by Cogbili and Likens versus the $\mathrm{pH}$ calculated with the assumptions by Stensland, for the 1955-56 Junge data (from ref. 2).

PRECIPITATION CHEMISTRY IN CENTRAL. ILLINOIS IN 1954 AND 1977

The difference in the precipitation chemistry for a rural, east-central Illinois site in 1954 as compared to 1977 was investigated to ascertain whether or not the precipitation became more acidic and if so, why.* The 1954 data set ${ }^{6}$ was unique for its time

*This topic is covered in more detail in reference 1 and in a paper that has been submitted to the Journal of the Air Pollution Control Association. 


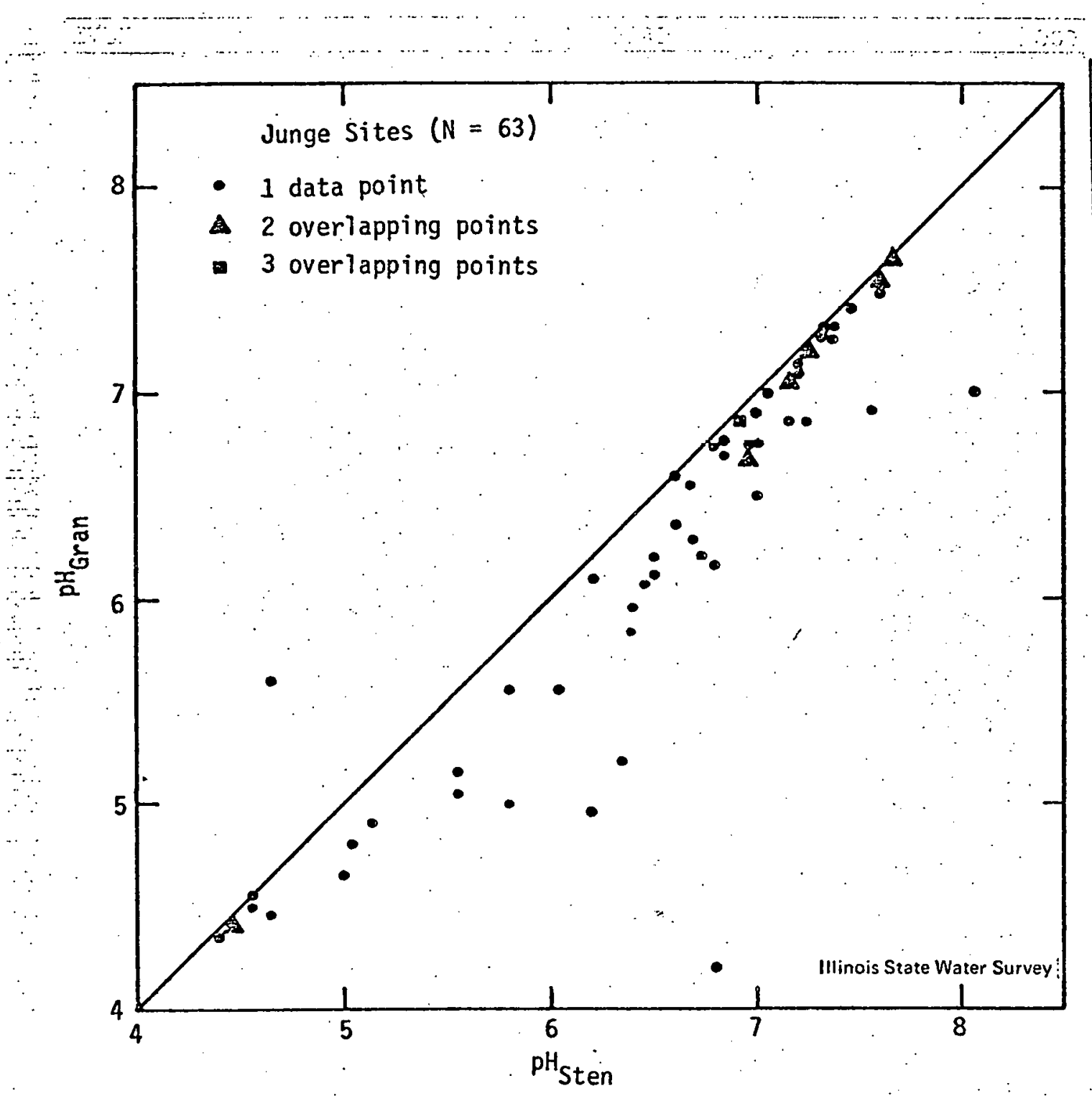

Figure 4. The pH calculated with the assumptions made by Granat versus the pH calculated with the assumptions by Stenslend, for the 1955-56 Junge data (froin ref. 2).

because the manual sampling technique carefully eliminated any dry deposition and because individual precipitation events were analyzed. The sampling site in both 1954 and 1977 was at the Champaign-Urbana airport (referred to as CNI), located 7 kilometers south of Champaign and surrounded by cultivated fields except for a golf course to the east. The data sets were collected from October 26, 1953 to August 12, 1954 and from llay 15, 1977 to February 6, 1979. For convenience the two sets will be referred to as the 1954 data and the 1977 data. 


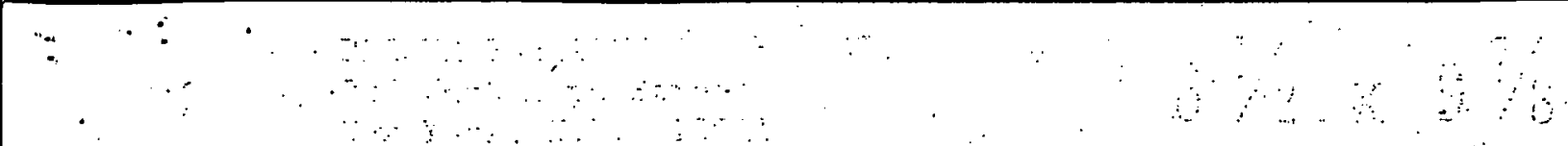

For the 1977 study an automatic collector, which exposed the wet-side bucket only during the time of precipitation, was used. The polyethylene bucket was changed within 24 hours of the end of the precipitation event and then brought immediately to the laboratory where $\mathrm{pH}$ and conductivity were measured followed by sample filtration with a 0.45 micrometer membrane filter. The ions $\mathrm{SO}_{4}^{\overline{4}}, \mathrm{NO}_{3}^{-}, \mathrm{Cl}^{-}, \mathrm{NH}_{4}^{+}, \mathrm{Ca}++\mathrm{Mg}^{++}, \mathrm{K}^{+}$, and $\mathrm{Na}^{+}$were determined by standard methods on AutoAnalyzer and atomic absorption. instruments. The sampling and analysis procedures for the 1954 data are described in detail in the Larson and Hettick paper. ${ }^{6}$

From about May is to September 30 the landscape around CMI is mostly green due to the corn and soybean crops. In the fall season most of the farmland is tilled, producing a brown landscape. Since the local dust conditions thus may be quite different for the two periods, the precipitation chemistry data for 1977 was divided into the green period events and the brown period events. The data for $\mathrm{pH}$ show that this potential dust effect was not large for the 1977 data set. Due to the relatively small number of data points for 1954 these events were not divided into brown and green periods. Three other types of data separation were carried out. First, in the 1954 data there were six precipitation events wherein consecutive samples were taken, so a volume-weighted average was computed for each ion. These average values were used in the subsequent analyses. Second, there were six events, also in the 1954 data, where the sample collection began after the precipitation had started. Because the chemical concentrations are highest at the beginning of precipitation events, these six samples were given special consideration. Third, for the 1977 samples the procedures allowed very small samples to be analyzed and these data were also noted separately.

The precipitation $\mathrm{pH}$ was not reported for the 1954 data so Eqs. 5, 6, and 7 were used to calculate the pH. The frequency distributions of the calculated $\mathrm{pH}$ for 1954 and for the measured $\mathrm{pH}$ for 1977 are presented in Figure 5. It can be seen that the median $\mathrm{pH}$ does not change significantly when the smaller samples are included, but the green period $\mathrm{pH}$ is somewhat lower than the brown period $\mathrm{pH}$. The 1977 combined brown and green period median $\mathrm{pH}$, for events $\geq 0.70 \mathrm{~mm}$, is 4.1 . This compares with the calculated median $\mathrm{pH}$ of 5.9 for the 1954 data. If those 1954 samples with precipitation at the beginning are excluded, the 1954 median $\mathrm{pH}$ is 6.05 . The more basic precipitation in 1954 could have resulted from low levels of acidic ions (e.g., sulfate and nitrate) or from high levels of basic ions (e.g., calcium and magnesium). This issue is addressed with.the data in Table 1 . For this table the small precipitation samples $(<0.70 \mathrm{~mm})$ were not included.

For sulfate in 1977 the median was $80 \mu \mathrm{\mu q} / \mathrm{l}$ for the brown period, $65 \mu \mathrm{eq} / \mathrm{l}$. for the green period, and $70 \mu \mathrm{eq} / 2$ for the com- 


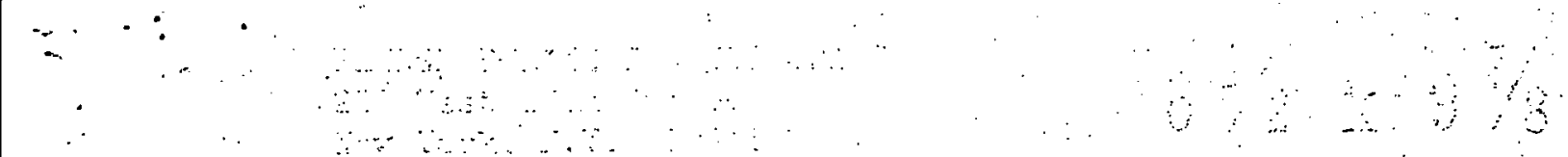

bined brown and green period. The median for 1954 was $50 \mu \mathrm{eq} / \mathrm{l}$, but when samples with precipitation at the beginning were excluded the 1954 median was $60 \mathrm{\mu eq} / \mathrm{l}$. As with sulfate, the 1977 nitrate values had a somewhat larger median for the brown period. The nitrate median was $38 \mathrm{\mu eq} / \mathrm{l}$ for the brow period, $28 \mathrm{\mu eq} / \mathrm{l}$ for the green period and $30 \mu \mathrm{eq} / \mathrm{l}$ for the combined brown and green periods. The 1954 median nitrate value was $18 \mu \mathrm{eq} / \mathrm{l}$ while the exclusion of samples with precipitation at the beginning increased the median to $20 \mathrm{\mu eq} / \mathrm{l}$. The hardness, defined as the sum of calcium and magnesium

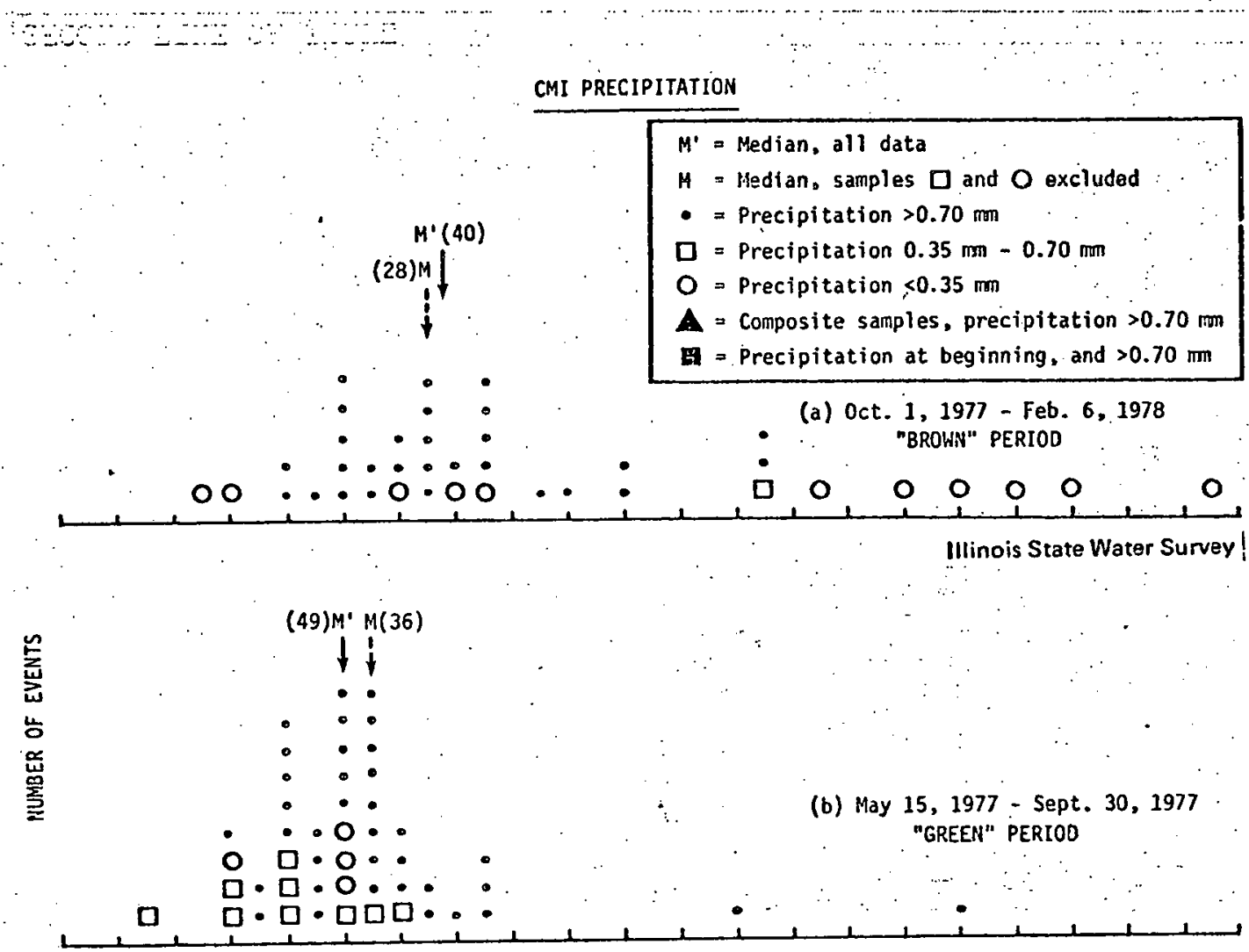

(c) Oct. 26, 1953 - Aug. 12, 1954 $M(38)$

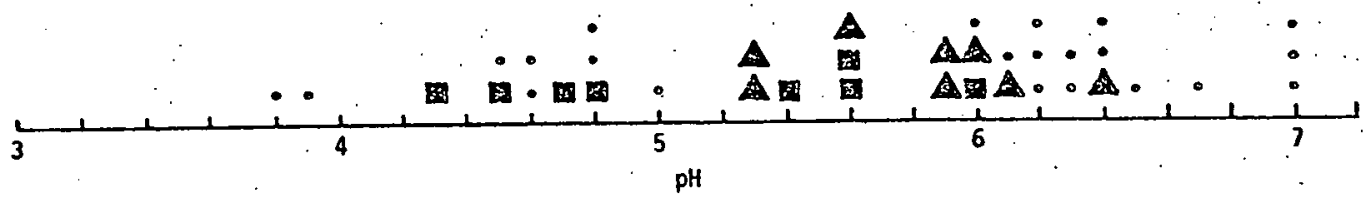

Figure 5. Frequency distribution of measured $\mathrm{pH}$ for 1977 precipitation events and calculated pH for 1954 precipitation events. The numbers in parentineses indicate the number of data points from which the median was obtained (from ref. 1). 


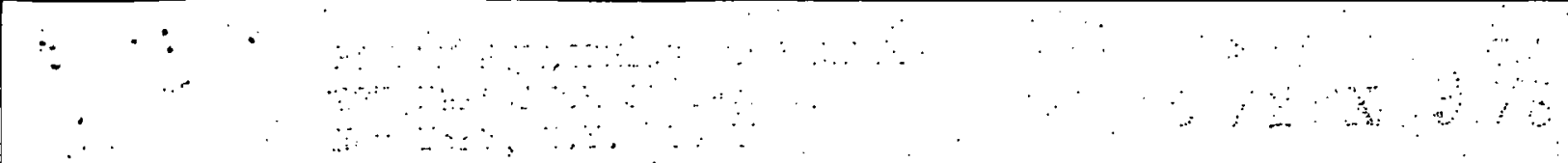

concentrations $\left(\mathrm{Ca}^{++}+\mathrm{Mg}^{++}\right)$, was reported for the 1954 data and therefore is the quantity presented in Table $I$. The median hardness value for 1977 for the combined green and brown period was 10 $\mu$ eq/l, with the brown period median being $15 \mu \mathrm{eq} / \mathrm{l}$ and the green period value being $10 \mu \mathrm{eq} / \mathrm{l}$. For 1954, the median hardness value was $65 \mu \mathrm{eq} / \mathrm{l}$, but when samples with precipitation at the beginning are excluded the median was $82 \mathrm{\mu eq} / \mathrm{l}$. Of the nine 1954 events with hardness greater than $100 \mu \mathrm{eq} / \mathrm{l}$, two were in the green period and seven in the brown period.

Table I. Ion concentrations ( $\mu$ eq $\ell^{-1}$ ) and $\mathrm{pH}$ for precipitation samples $(<0.70 \mathrm{~mm})$.

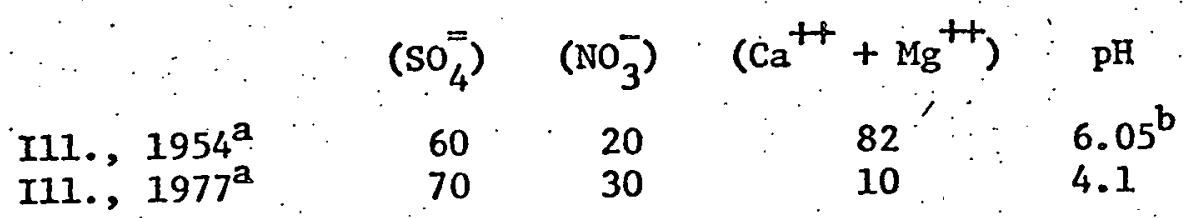

Median values for CMT event samples.

b Includes the empirical correction for calculated $\mathrm{pH}$. Without this correction the value would be about 6.75 .

With the data summarized in Table $I$ there can be little question that the CMI samples in 1954 were much more basic than the 1977 samples. Although both $\mathrm{SO}_{4}^{=}$and $\mathrm{NO}_{3}^{-}$were apparently lower in the 1954 samples, it was the high concentrations of soil related species, Cat+ and $\mathrm{Mg}^{++}$, which produced the high $\mathrm{pH}$ in 1954. If the $\mathrm{Ca}^{++}+\mathrm{Mg}^{++}$concentration in 1954 had been $10 \mu \mathrm{eq} / \mathrm{l}$ (the 1977 level), the $\mathrm{pH}$ would have been 4.17 instead of 6.05 . The median $\mathrm{pH}=6.05$ for 1954 includes the empirical correction in Eqs, 6 and 7 . Without this correction the 1954 median $\mathrm{pH}$ value would have been about 6.75, and 4.34 with the 1977 level of $\mathrm{Ca}^{++}+\mathrm{Mg}^{++}$.

The high $1954 \mathrm{Ca}^{++}+\mathrm{Mg}^{++}$concentration could have resulted from problems in the chemical analysis procedures, or may be indicative of higher ambient air levels of these elements in 1954. Recent work at the Illinois State Water Survey has show that the $\mathrm{Ca}^{++}+\mathrm{Mg}^{++}$levels in rain can rise considerably with time if the samples are not filtered. ${ }^{7}$ The 1977 samples were filtered but most of the 1954 samples were not. There are other preliminary data, however, which suggest that the absence of filtering will not account for the majority of the increase in the $1954 \mathrm{ph}$ levels compared to the 1977 values. 


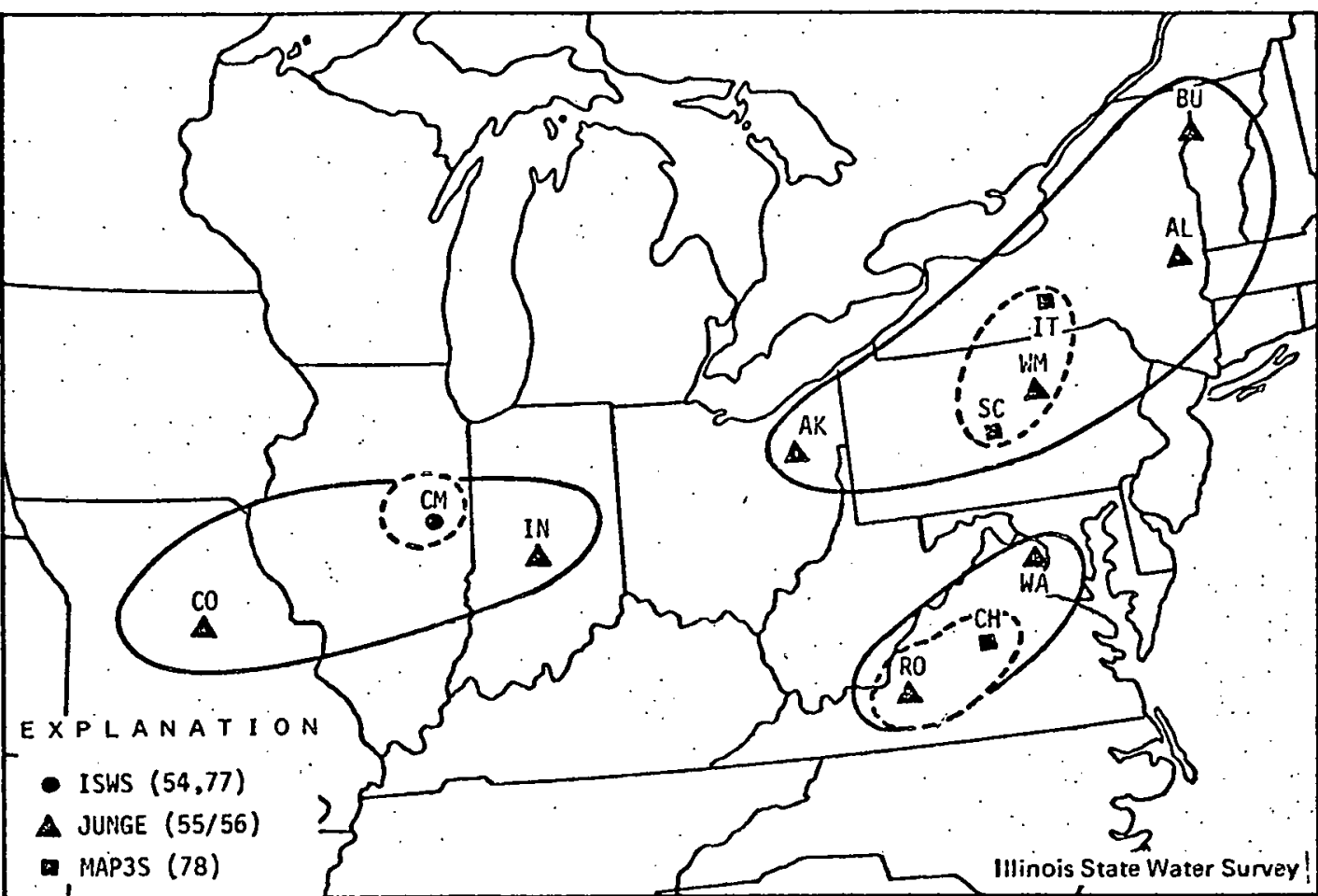

Figure 6. Location of precipitation chemistry sampling sites in the northeastern United States. The dashed lines enclose the prinary sites being compared while the solid lines enclose additional sites for which data are presented (from ref. 8).

The Junge network consisted of 62 sites distributed across the continental United States. Data from eight of the sites will be used in this paper. The dashed lines in Figure 6 enclose those sites considered most important for the present analysis while the solid lines indicate the additional sites which provide comparative data.

The type of precipitation chemistry data needed for this study were ion concentrations for wet-only samples. That is, evaporation losses and dry deposition effects had to be absent. There are data available from some networks where automatic wet-only collectors were used but where the protective cover did not make a tight seal with the sample container. Evaporation and contamination during non-rain periods probably occurred and therefore such data were not used.

For the MAP3S sites, an automatic wet-only sampler is used to collect event samples, where event refers basically to a daily sample. The collecting funnel is thoroughly rinsed after each 

Table III. Sulfate concentrations in precipitation (mg/l as $\mathrm{SO}_{4} \Rightarrow$ ) and ratios of recent values to historical values (from ref. 8).

MIDWEST

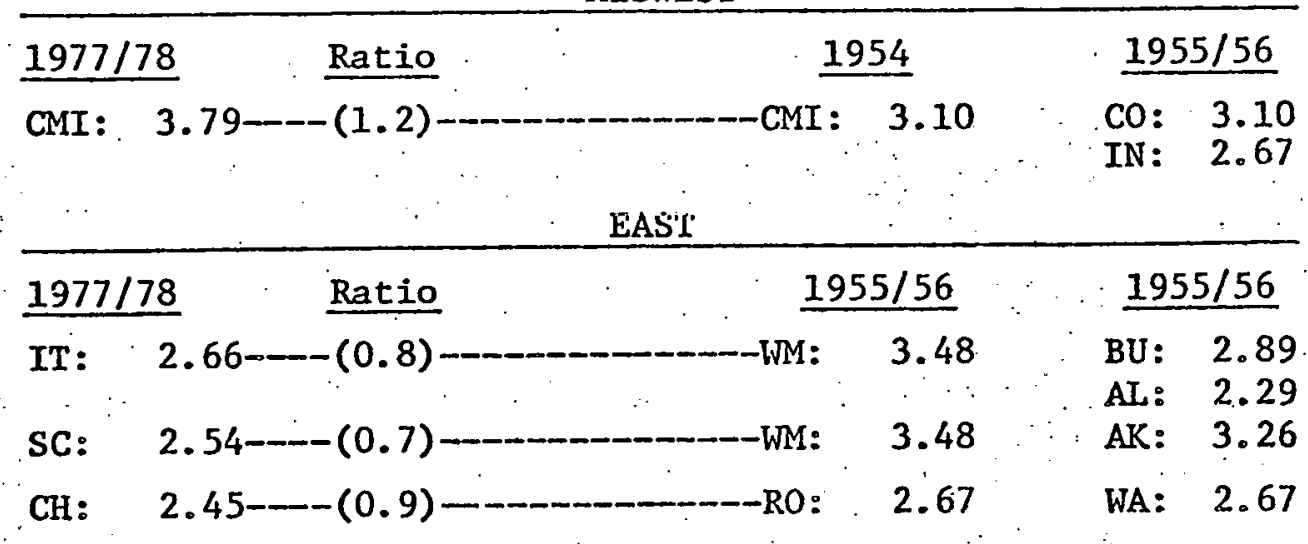

Table IV. Nitrate concentrations in precipitation (mg/l as $\mathrm{NO}_{3}{ }^{-}$) and ratios of recent values to historical values (from ref. 8).

MIDWEST

\begin{tabular}{llll}
\hline $1977 / 78$ & $\frac{\text { Ratio }}{(1.5)}$ & $\frac{1954}{1.25}$ & $\frac{1955 / 56}{\text { CO: } .58}$ \\
CMI: 1.85 & IN: $_{0}$ & .53
\end{tabular}

EAST

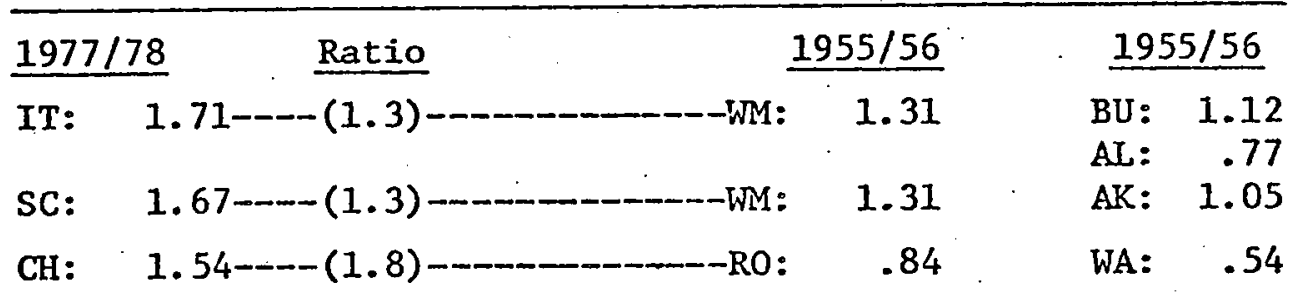

tions are given. For the Junge data the monthly compositing procedure produced sample volume weighted concentrations. Since the Junge data and the MAP3S data are to be compared, the MAP3S sample volume weighted averages are listed in Tables III and IV instead of the median values. 


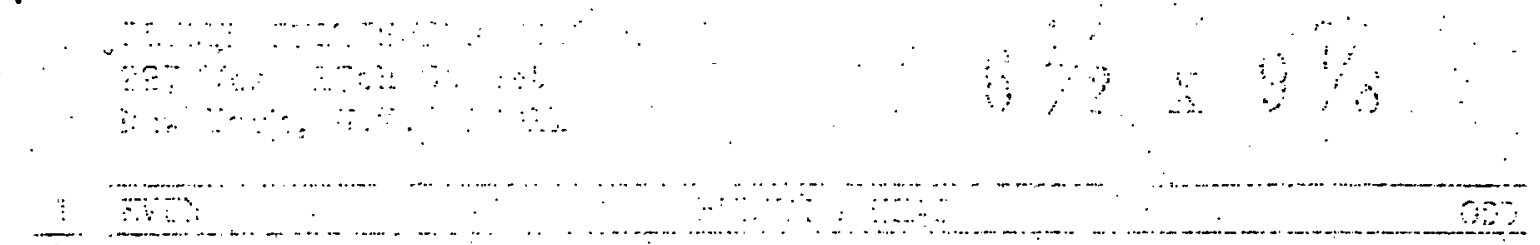

The upper portion of Table III gives the sulfate data for the midwestern site and the lower portion presents the data for the eastern sites. The dotted lines connect those sites for which it is considered most appropriate to calculate ratios between the recent and the older concentrations. The right hand column provides additional data for comparison to the middle column. The same format is used in Table IV. The basic feature to note in the tables is that the sulfate ratios are near one, while those for nitrate are greater than one. These trends will now be compared to the source emissions trends.

The emissions data which are presented in this section are values for the entire United States. It is assumed that the trends for these emissions data are representative of the sources contributing to the precipitation quality sites in the northeastern United States. A study of the geographical distribution of the 1972 emissions data has shown that the EPA air quality regions I-IV (basically the eastern United States) contributed $80 \%$ of the total nitrogen oxide emissions. ${ }^{12}$ The same study showed that six states, New York, Pennsylvania, Ohio, Michigan, Indiana, and Illinois, contributed $45 \%$ of the total. For sulfur oxides the study indicated that the northeast sector of the United States accounted for about half of the total sulfur oxide emissions.

It is generally accepted that the anthropogenic sources dominate over natural sources for industrialized areas such as the Northeast. Of the various sources categories, fossil fuel combustion at stationary sources dominates for the sulfur oxides. ${ }^{3}$ In 1970 about $78 \%$ of the sulfur oxides were emitted from these sources. Steam electric power plants were the major stationary sources and they contributed $57 \%$ of the total sulfur oxide emissions. In total, coal combustion accounted for about $65 \%$ of the total sulfur oxide emissions. For nitrogen oxides, gasoline combustion in motor vehicles accounted for $34 \%$ of the total emissions in 1970 while coal, fuel oil, and natural gas combustion in stationary sources accounted for $44 \%$ of the total. ${ }^{13}$

The time trend of the estimated emissions is sumarized in Table V. The EPA report providing the data for the lower half of Table $V$ warned that the earlier estimates (upper half of Table $V$ ) had not been calculated in exactly the same way and thus would not be exactly comparable. This explains why, for instance, the two 1970 estimates for sulfur oxides do not agree exactly. The data in these tables are expressed as $\mathrm{SO}_{2}$ and $\mathrm{NO}_{2}$. In Table VI the data from Table $V$ have been normalized by making the two 1970 values agree. This normalization procedure is a reasonable and practical approach that allows the 1940 to 1976 time period to be examined. Table VI shows that nitrogen oxide emissions have increased much more than sulfur oxide emissions. From mid-1950 to 1976, nitrogen oxides increased from about 11 to 23 million metric tons per year, 
Table V. Estinated nitrogen oxide and sulfur oxide emissions for the continental United States (millions of metric tons per year).

$\begin{array}{lrrrr} & \frac{1940}{} & \frac{1950}{1960} & \frac{1970}{} \\ \begin{array}{lrrrr}\text { Nitrogen Oxides } \\ \text { Sulfur Oxides }\end{array} & 7.2 & 9.4 & 12.7 & 20.6 \\ 19.5 & 21.6 & 21.1 & 30.8\end{array}$

\begin{tabular}{|c|c|c|c|c|c|c|c|}
\hline & 1970 & 971 & 1972 & 3 & 4 & & \\
\hline & & & & & & & \\
\hline
\end{tabular}

Source: Reference \#13 (p. 4, Table 1)

bource: Reference 非 (p. 5-1, Table 5-1)

Table VI. Normalized emissions estimates as calculated from Table V (millions of metric tons per year).

\begin{tabular}{|c|c|c|c|c|c|c|c|c|c|c|c|}
\hline & & & & & 19 & & 19 & 60 & \multicolumn{2}{|c|}{1970} & \\
\hline & $\begin{array}{l}\text { Nitroge } \\
\text { Sulfur }\end{array}$ & $\begin{array}{l}\text { n Oxides } \\
\text { Oxides }\end{array}$ & & & & 4 & $\begin{array}{l}12 \\
19\end{array}$ & & & & \\
\hline & & 1970 & 1971 & & 72 & & 73 & & 74 & 1975 & 1976 \\
\hline $\begin{array}{l}\text { itrogen } \\
\text { ulfur } 0\end{array}$ & $\begin{array}{l}\text { Oxides } \\
\text { xides }\end{array}$ & $\begin{array}{l}20.4 \\
29.1\end{array}$ & $\begin{array}{l}21.3 \\
27.9\end{array}$ & & & & .9 & & $\begin{array}{l}.6 \\
.2\end{array}$ & $\begin{array}{l}22.2 \\
25.7\end{array}$ & 26 \\
\hline
\end{tabular}

a factor of 2.1. At the same time, sulfur oxides increased from about 20 to 27 million metric tons per year, a factor of 1.3 . The relatively small increase in the sulfur oxide emissions is explained by the fact that natural gas and low sulfur oil and coal have become tiore heavily used since the mid-1950's. 15 The larger growth rate in the nitrogen oxide emissions is due to the large increases in energy consumption for electric power and transportation. From 1955 to 1970 the former increased by a factor of 2.6 and the latter by a factor of 1.6.15

\section{CONCLUSIONS}

The results in this paper. suggest that at present the best approach to calculating the $\mathrm{pH}$ of a precipitation sample is to assume that a charge balance exists and then to apply an empirical correction, as expressed in Eqs. 6 and 7. With this approach the 
1977 central IIlinois samples are shown to be much more acid than those from 1954. The primary reason for this $\mathrm{pH}$ decrease is the decreased concentration of calcium and magnesium in the samples.

For the mid-1970's compared to the mid-1950's the source emissions estimates for the United States were up by a factor of 1.3 for sulfur and 2.1 for nitrogen. During this same time interval the sulfate concentrations for the precipitation chemistry sites in the northeastern United States remained about the same and the nitrate concentrations increased by factors varying from 1.3 to 1.8. Since the emissions estimates increased more than the precipitation concentrations, it would seen that a smaller fraction of the pollutants were being removed over the northeast by wet processes in the mid-1970's than in the mid-1950's. This could be a result of the trend towards the use of taller stacks. However, the data presented in this paper are very limited both spatially and temporally so the conclusion should be considered as rather speculative.

\section{ACKNOWLEDGMENTS}

The author thanks S. A. Changnon, Jr. and R. G. Semonin for general supervision of this work. The analytical chemistry support of the team of F. F. McGurk and L. M. Skowron under the leadership of M. E. Peden is also gratefully acknowledged. This work was sponsored by the U. S. Department of Energy under contract EX-1199.

\section{REFERENCES}

1. G. J. Stensland, A comparison of precipitation chemistry data at Champaign, Illinois in 1954 and in 1977, in Chapter 3 of the 16th Prog. Rept. on Cont. EY-76-S-02-1199, II1. State Water Survey, Urbana, IL (1978).

2. G. J. Stensland, Calculating precipitation $\mathrm{pH}$, in preparation for the 17th Prog. Rept. on Cont. EY-76-S-02-1199, I11. State Water Survey, Urbana, IL (1979).

3. L. Granat, On the relationship between $\mathrm{pH}$ and the chemical composition in atmospheric precipitation, Tellus, 24:550 (1972).

4. C. V. Cogbill and G. E. Likens, Acid precipitation in the northeastern United States, Water Resour. Res., 10:1133 (1974).

5. C. E. Junge, "Air Chemistry and Radioactivity," Academic Press, New York, (1963).

6. T. E. Larson and I. Hettick, Mineral composition of rainwater, Tellus, 8:191 (1956).

7. M. E. Peden and L. M. Skowron, Ionic stability of precipitation samples, Atmos. Environ., 12:2343 (1978): 
8. G. J. Stensland, A comparison of sulfate and nitrate in precipitation in 1955 and 1977 to emissions and air quality trends, in preparation for the 17th Prog. Rept. on Cont. EY-76-S-02-1199, I11. State Water Survey, Urbana, IL (1979).

9. Battelle, The MAP3S Precipitation Chemistry Network: First Periodic Summary Report (September 1976-June 1977), Battelle Northwest Laboratories, Richland, Washington, Report No. PNL-2402, October 1977.

10. T. Dana, D. Drewes, S. Harris, J. Rothert, Monthly data summaries of MAP3S precipitation chemistry data, Battelle Northwest Laboratories, Richland, Washington.

11. C. E. Junge and $\bar{P}$. E. Gustafson, Precipitation sampling for chemical analysis, Bul1. Am. Meteoro. Soc., 37:244 (1956).

12. National Research Council, Air Quality and Stationary Source Enission Control, prepared for the United States Senate Comittee on Public Works, August (1973).

13. J. H. Cavender, D. S. Kircher, and A. J. Hoffnan, Nationwide Air Pollutant Emission Trends 1940-1970, Office of Air Quality Planning and Standards, USEPA, Research Triangle Park, NC, Publication. No. AP-115, January (1973).

14. U. S. Environmental Protection Agency, National Air Quality and Emissions Trends Report, 1976, Office of Air Quality Planning and Standards, Research Triangle Park, NC, Publication No. EPA-450/1-77-002, December (1977).

15. E. Cook, The flow of energy in an industrial society, Sci. Amer., 225, 137 (1971). 